\begin{tabular}{|c|l|}
\hline Title & $\begin{array}{l}\text { Expression of GnRH genes is elevated in discrete brain loci of chum sal mon before initiation of homing behavior and } \\
\text { during spawning migration }\end{array}$ \\
\hline Author(s) & $\begin{array}{l}\text { Onuma, Takeshi A.; Makino, Keita; A ndo, Hironori; Ban, Masatoshi; Fukuwaka, Masa aki; A zumaya, Tomonori; } \\
\text { Urano, A kihisa }\end{array}$ \\
\hline Citation & $\begin{array}{l}\text { General and Comparative Endocrinology, 168(3), 356-368 } \\
\text { https://doi.org/10.1016/.ygcen.2010.05.001 }\end{array}$ \\
\hline Issue Date & 2010-09-15 \\
\hline Doc URL & http://hdl.handle.net/2115/43854 \\
\hline Type & article (author version) \\
\hline Additional Information & There are other files related to this item in HUSCAP. Check the above URL. \\
\hline File Information & GCE168-3_356-368.pdf \\
\hline
\end{tabular}

Instructions for use 
General and Comparative Endocrinology $\left(2^{\text {nd }}\right.$ revision $)$

\section{Expression of GnRH genes is elevated in discrete brain loci of chum salmon before initiation of homing behavior and during spawning migration}

Takeshi A. Onuma ${ }^{1-2)}$, Keita Makino ${ }^{2)}$, Hironori Ando ${ }^{1)}$, Masatoshi Ban ${ }^{3)}$, Masa-aki Fukuwaka ${ }^{4)}$, Tomonori Azumaya ${ }^{4)}$ and Akihisa Urano ${ }^{2)}$

${ }^{1}$ Graduate School of Bioresource and Bioenvironmental Sciences, Kyushu University, Fukuoka 812-8581, Japan, ${ }^{2}$ Section of Biological Sciences, Graduate School of Life Sciences, Hokkaido University, Sapporo 060-0810, Japan, ${ }^{3}$ National Salmon Resources Center, Fisheries Research Agency, Sapporo 062-0922, Japan, ${ }^{4}$ Hokkaido National Fisheries Research Institute, Fisheries Research Agency, Kushiro 085-0802, Japan.

[Abbreviated title] GnRH and homing migration

[Address all correspondence and reprint request] Takeshi A. Onuma, Graduate School of Bioresource and Bioenvironmental Sciences, Kyushu University, Fukuoka 812-8581, Japan. Present address: Molecular, Cellular, and Developmental Biology, University of Michigan 830 N. University, Ann Arbor, MI 48105.

Phone: +1-734-929-7372, E-mail: takeshikiai@msn.com

[Keywords] spawning migration; chum salmon; gonadotropin-releasing hormone; brain; gonad; pituitary-gonadal axis; behavior

[Number of text pages] 37 [Number of figures] 10

[Number of supplemental figures] 4 


\begin{abstract}
Our previous studies suggested the importance of gonadotropin-releasing hormones (GnRHs) for initiation of spawning migration of chum salmon, although supporting evidence had been not available from oceanic fish. In farmed masu salmon, the amounts of salmon GnRH (sGnRH) mRNAs in the forebrain increased in the pre-pubertal stage from winter through spring, followed by a decrease toward summer. We thus hypothesized that gene expression for GnRHs in oceanic chum salmon changes similarly, and examined this hypothesis using brain samples from winter chum salmon in the Gulf of Alaska and summer fish in the Bering Sea. They were classified into sexually immature and maturing adults, which had maturing gonads and left the Bering Sea for the natal river by the end of summer. The absolute amounts of GnRH mRNAs were determined by real-time PCRs. The amounts of sGnRH mRNA in the maturing winter adults were significantly larger than those in the maturing summer adults. The amounts of sGnRH and chicken cGnRH-II mRNAs then peaked during upstream migration from the coast to the natal hatchery. Such changes were observed in various brain loci including the olfactory bulb, terminal nerve, ventral telencephalon, nucleus preopticus parvocellularis anterioris, nucleus preopticus magnocellularis and midbrain tegmentum. These results suggest that sGnRH neurons change their activity for gonadal maturation prior to initiation of homing behavior from the Bering Sea. The present study provides the first evidence to support a possible involvement of neuropeptides in the onset of spawning migration.
\end{abstract}




\section{Introduction}

Neurons that secrete gonadotropin-releasing hormone $(\mathrm{GnRH})$ are typical neuroendocrine cells in the forebrain. They regulate concordantly the function of the pituitary-gonadal (PG) axis and reproductive behavior (Rissman, 1996; Urano et al., 1999). There are two or three GnRH forms in single vertebrate species (Okubo and Nagahama, 2008). In salmonids, two molecular forms of GnRH were identified: salmon GnRH (sGnRH) and GnRH-II (cGnRH-II). Salmon GnRH neurons are scattered in the ventral part of forebrain, that is, olfactory bulb (OB), terminal nerve (TN), ventral telencephalon (VT), nucleus preopticus parvocellularis anterioris $(\mathrm{PPa})$ and nucleus preopticus magnocellularis (PM) (Amano et al., 1998; Suzuki et al., 1992), while cGnRH-II neurons are localized in the midbrain tegmentum (MT) (Amano et al., 1997).

Salmon GnRH released from hypophysial terminals of VT and PPa neurons are considered to control function of the salmonid PG axis (Amano et al., 1997), while GnRH neurons in other brain loci are suggested to be involved in neuromodulation. Immunoreactive sGnRH and cGnRH-II fibers are distributed in various brain loci including the optic tectum and the hypothalamic neurosecretory nucleus. GnRHs directly stimulated electric activities of preoptic neurosecretory neurons (Saito et al., 2003) and facilitated synaptic transmission of retinotectal neurons (Kinoshita et al., 2007).

The spawning migration of chum salmon was classically considered as a one-time seasonal reproductive behavior that covers thousands of miles (Salo, 1991). However, it actually covers multiple seasons from winter to autumn. Chum salmon of Japanese population, which return their natal river for spawning, leave the Gulf of Alaska for the Bering Sea from winter to spring (Urawa, 2000) and spend several months in the central Bering Sea during early summer (Moriya et al., 2007; Sato et al., 2007). Homing adults, which leave the Bering Sea, require a few months to reach their natal river in Japan (Tanaka et 
al., 2005), migrate up the natal river, and finally mature to spawn in autumn. We recently demonstrated that the elevation of the PG-axis activity and resulting gonadal development are important endocrine events that are inseparable from the onset of spawning migration from the summer Bering Sea (Onuma et al., 2009a). These events were triggered earlier than 6 months prior to the breeding season, because maturing adults which had developing gonads were seen even in the Gulf of Alaska in February. These results suggest an importance of GnRH, although there is still little information about when, where and how activity of GnRH neurons change along with the onset of spawning migration.

In pond-reared masu salmon, the amounts of sGnRH mRNA in the forebrain showed biphasic peaks during the year when the fish spawned (Ando et al., 2001; Kitahashi et al., 2004). The earlier peak was seen in the pre-pubertal stage in winter to early spring, declined toward summer, and followed by the later peak in the spawning period in autumn. Activity of the hypothalamus-pituitary-gonadal axis (HPG-axis) of chum salmon seemed to change similarly in the year when they showed spawning migration. It is true in the spawning period, because the amounts of sGnRH mRNA in almost all the loci of forebrain and those of luteinizing hormone (LH) $\beta$ mRNA in the pituitary increased during upstream migration in the long Ishikari River (Kitahashi et al., 1998a; Onuma et al., 2005) and the short Otsuchi River (Onuma et al., 2003b). However, no studies have been addressed to clarify gene expression for GnRHs when maturing chum salmon are migrating in the Gulf of Alaska, and also during the phase when fish initiate homing behavior from the summer Bering Sea.

In the present study, we examined gene expression for GnRHs prior to the onset of spawning migration of chum salmon. For this purpose, we used brain samples that were previously collected along the presumed pathway of spawning migration of Japanese population (Onuma et al., 2009a). The sampling locations included the winter Gulf of Alaska, the summer Bering Sea and also homing pathway in the Ishikari River-Ishikari bay 
water system in Hokkaido, Japan in the spawning period in autumn. Absolute amounts of sGnRH and cGnRH-II mRNAs in discrete brain loci were determined by the quantitative real-time polymerase chain reaction (PCR) assay developed in our laboratory (Kitahashi et al, 2004), because quantitative information is crucial to compare the data from fish collected in different sampling areas, different seasons, and different years. From the same fish, we previously assessed the activity of the PG-axis on the basis of the amounts of gonadotropin (GTH) subunit mRNAs, the contents of follicle-stimulating hormone (FSH) and LH in the pituitary, and the plasma levels of FSH, testosterone (T), 11-ketotestosterone (11KT) and estradiol-17 $\beta$ (E2) (Onuma et al., 2009a), and insulin-like growth factor-I (IGF-I) (Onuma et al., 2009b: Onuma et al., 2010a). The present study enabled us to understand activity of the HPG-axis of chum salmon along with the onset of spawning migration.

\section{Materials and methods}

\subsection{Oceanic chum salmon}

Chum salmon, Oncorhynchus keta Walbaum, were caught in the central Bering Sea in summer and autumn from 2001 to 2003, and in the Gulf of Alaska in winter in 2006. They were collected by several oceanic research cruises. The fishing methods and locations of fishing stations are described in our previous report (Onuma et al., 2009a). Chum salmon in the Bering Sea form mixed populations whose stocks originate in the North Pacific Rim. A considerable portion of chum salmon in these areas belonged to Japanese populations (Moriya et al., 2007; Sato et al., 2006; Sato et al., 2007).

The oceanic chum salmon used in the present study were previously grouped as immature, maturing adult I and maturing adult II by histological diagnosis of gonads (Onuma et al., 2009a). The activity of the PG-axis in the same fish was previously assessed from the absolute amounts of mRNAs for glycoprotein (GP) $\alpha 2$, FSH $\beta$ and LH $\beta$ in the pituitary, the 
pituitary contents of FSH and LH, and the plasma levels of FSH, T, 11KT and E2 (Onuma et al., 2009a). Mother country of oceanic chum salmon was identified by use of oligonucleotide microarray which detects the single nucleotide polymorphisms in the 5' half of the control region of mitochondrial DNA (mtDNA) (Moriya et al., 2004), because oceanic chum salmon are a mixture of Japanese, Russian and North American populations (Sato et al., 2004). Nonetheless, the parameters of the PG-axis activity were within a similar range when the present fish were divided into clade A (Japanese population) and clade B (common haplotypes in the Pacific Rim) (Onuma et al., 2009a). In the present study, data from all haplotypes were therefore pooled and treated as immature or maturing groups.

The populations of chum salmon in the Bering Sea and the Gulf of Alaska were a mixture of immature fish and maturing adults (Onuma et al., 2009a). In terms of gonadal development, the gonadosomatic indices (GSI, gonad weight/body weight $x$ 100) of the maturing adults were more than 2-fold those of immature fish. Since almost all fish captured in the Bering Sea were immature in September, the maturing adults evidently left the Bering Sea for the natal river by late summer. Gonadal development of oceanic chum salmon was started more than 6 months prior to the spawning period in autumn, because about $30 \%$ of the males and $45 \%$ of the females were maturing adult I fish in the Gulf of Alaska in February 2006. In the maturing adults, the amounts of GTH subunit mRNAs, the contents of FSH and LH in the pituitaries, and the plasma levels of T, $11 \mathrm{KT}$ and E2, were 10- to 100-fold those in the immature fish (Onuma et al., 2009a). The maturing adults in the present study were thus regarded as homing fish that migrate up the natal river in the coming breeding season.

\subsection{Homing chum salmon}

In the spawning period in autumn from 2001 to 2003, homing adults were captured along their homing route in the Ishikari River-Ishikari bay water system in Hokkaido, Japan. 
They are the same fish used in Onuma et al. (2009a). In brief, fish were caught at Esashi along the northeast (NE) coast of Hokkaido in the Sea of Okhotsk, in the Ishikari bay, estuary at the river mouth, the midway point of upstream migration located at the junction of the mainstream of the Ishikari River and the Chitose River, the upstream point at $4 \mathrm{~km}$ downstream of the hatchery, and the natal hatchery in the Chitose Field Station (See Onuma et al., 2009a). The distance from the mouth of the Ishikari River to the hatchery is about $70 \mathrm{~km}$. The previous data logger analyses showed that homing chum salmon spent a few weeks to reach the hatchery from the mouth of the Ishikari River (Kitahashi et al., 2000; Makino et al., 2007). Almost all males had spermiated by the time they arrived at the upstream point of the Chitose River, whereas all females ovulated at the hatchery (Onuma et al., 2009a). Homing adults therefore completed final maturation at or near the hatchery as previously reported (Onuma et al., 2003a; Onuma et al., 2005). These stable reproductive phenomena in early to mid-2000's might be derived from rather stable oceanic environments during this period, in contrast to 1990’s (Saito et al., 2001; Onuma et al., 2003).

\subsection{Tissue sampling}

All sampling procedures were carried out under the guideline of animal care of Hokkaido University. Following a blow to the head, folk length and body weight were measured (see Onuma et al., 2009a), and blood samples were collected from the caudal vasculature for assays of sex steroid hormones. Spermiation or ovulation was checked by gentle massage of the abdomen. Brains and pituitaries were removed immediately after decapitation. The caudal part of brain behind the cerebellum was trimmed off, and the brain samples were frozen in isopentane cooled with liquid nitrogen. They were stored at $-80^{\circ} \mathrm{C}$ until total RNA was extracted. The amounts of GTH subunit mRNAs and FSH and LH in the pituitaries of the same individuals were determined in our previous study (Onuma et al., 
2009a). The gonads were removed and weighed to calculate GSI. A portion of the testes and ovaries were fixed in Bouin's solution for one day, then replaced with $70 \%$ ethanol, and stored at $4^{\circ} \mathrm{C}$ for later histological analyses. The ages of fish were estimated as 2-, 3- or 4-year-old (Onuma et al., 2009a), when estimated from the number of annuli in the scale, as previously reported (Davis et al., 1990).

\subsection{Preparation of samples}

In the salmonid brain, sGnRH neurons longitudinally scatter in the ventral part of the forebrain, i.e., the OB, TN, VT, PPa and PM (Amano et al., 1998; Suzuki et al., 1992), while cGnRH-II neurons are localized in the MT (Amano et al., 1997). The brain samples were thus divided into nine regions (Fig. 1) to determine the amounts of GnRH mRNAs in discrete loci by our established method (Onuma et al., 2005). The frozen brains were cut into 25- $\mu$ m-thick serial transverse sections from the rostral part of OB through the saccus vasculosus with a cryostat (CM 3000, Leica, Nussloch, Germany) after removal of the optic tectum. Every tenth sections were Nissl-stained to ascertain the exact locus of cutting place. Afterward, the other sections were separated into nine loci: 1, rostral OB (ROB) including the olfactory nerve; 2 , OB; 3 , caudal part of $\mathrm{OB}(\mathrm{COB})$ that contains the stratum granulare; 4, TN; 5, VT; 6, PPa; 7, PM pars parvocellularis (PMp) and PM pars magnocellularis (PMm); 8, PM pars gigantocellularis (PMg) and infundibular region including the nucleus tuberis (NT); 9, mesencephalic region including MT. They were transferred into a sterile $1.5 \mathrm{ml}$ tube, and stored at $-80^{\circ} \mathrm{C}$. The number of frozen sections pooled in each tube ranged from 20 to 300 .

Total RNA was extracted from the brain sections by the guanidium thiocyanate/hot phenol method (Chirgwin et al., 1979). The total RNA was treated with $1 \mathrm{U}$ of deoxyribonuclease I (TaKaRa Biochemicals, Shiga, Japan) to degrade genomic DNA. Integrity of total RNA was confirmed by agarose gel electrophoresis, and the amounts of total 
RNA were determined with a NanoDrop ND-1000 Spectrometer (NanoDrop Technologies, Inc., Wilmington, DE). The concentration of total RNA from the individual loci of brain ranged between 50 and $1500 \mathrm{ng} / \mu \mathrm{l}$. The recovery rate of extraction and precipitation protocol was confirmed to be about $80 \%$ using known amounts of total RNAs from the forebrain of chum salmon (Onuma et al., 2005). The first strand cDNAs were synthesized from 200 ng of the total RNA using an oligo d(T) $)_{12-18}$ primer (GIBCO BRL, Tokyo, Japan) as previously described (Onuma et al., 2005). They were diluted to 1:10, and used as sample cDNAs.

\subsection{Quantitative real-time PCR assays of GnRH mRNAs}

Gene expression for sGnRH and cGnRH-II was assessed by quantification of the absolute amounts of GnRH mRNAs. We utilized the established protocol in which cDNA transcribed from the known number of copies of single-stranded RNA was used to describe a standard curve (Onuma et al., 2005). Such quantification of absolute amounts of hormonal mRNA enables us to directly compare data that were collected from chum salmon in different sampling areas, different season, and different years. Internal reference RNA like $\beta$-actin and GADPH was not used to normalize the amounts of target RNAs, because expression of housekeeping genes can vary depending on physiological states (Bustin, 2000).

Two sGnRH genes, sGnRH-I and sGnRH-II, are co-expressed in the salmonid brain (Ashihara et al., 1995; Higa et al., 1997). The expression level of sGnRH-II gene is much higher than that of sGnRH-I gene, as the amounts of mRNA for sGnRH-II mRNA in all the loci of the forebrain were 2- to 20-fold those for sGnRH-I mRNA in masu salmon (Ando et al., 2001) and chum salmon (Onuma et al., 2005). The pattern of changes in the amounts of sGnRH-I and -II mRNAs were similar during gonadal maturation (Ando et al., 2001; Onuma et al., 2005). In the present study, we thus determined the amounts of sGnRH-II mRNA, and 
referred to them as the amounts of sGnRH mRNA.

Partial cDNA encoding cGnRH-II was isolated to design primers and probe for real-time PCR. Total RNA of a whole brain of chum salmon was reverse transcribed using an oligo $d(\mathrm{~T})_{12-18}$ primer and Multiscribe Reverse Transcriptase (PE Applied Biosystems, Foster, CA, USA) according to the manufacturer's protocol. The cDNA served as a template for PCR amplification with primers, 5'-TAGACTGGTGTTTATGCTGGG-3' (forward) and 5'-CAGCGAAGGAACATCCT TAA-3' (reverse), corresponding to the sequences of signal peptide and GnRH-associated peptide of rainbow trout cGnRH-II cDNA (Von Schalburg and Sherwood, 1999). The PCR fragments of expected size (approximately 200 bp) were purified by a QIAquick Gel Extraction Kit (QIAGEN, Hilden, Germany), cloned into a pCR-Script Amp SK(+) cloning vector (STRATAGENE, CA, USA), and the nucleotide sequence was determined by the dideoxy chain-termination method (Sanger et al., 1977) using a SQ-5500 DNA sequencer (Hitachi, Tokyo, Japan). Five clones containing the insert were sequenced. The similarity of the partial cGnRH-II cDNA sequences between chum salmon and rainbow trout were confirmed as $99 \%$ (data not shown).

Absolute amounts of sGnRH and cGnRH-II mRNA were determined by use of standard sense RNAs to prepare standard curves. For sGnRH mRNA, standard sense RNA was synthesized as previously described (Onuma et al., 2005). For cGnRH-II mRNA, the plasmid DNA that contains the partial cGnRH-II cDNA insert was digested by restriction enzyme Not I, just after 3' end of the insert. Standard sense RNA was synthesized with a MAXIscript $^{\mathrm{TM}}$ kit (Ambion Inc, Austin, TX, USA) according to the manufacturer's instructions. The synthesized RNA was quantified with a NanoDrop ND-1000 Spectrometer, and used as the standard sense RNA. Serially diluted standard RNAs $\left(2.0 \times 10^{3}-2.0 \times 10^{9}\right.$ copies) were reverse-transcribed with gene specific primers (sGnRH: 5'-CACTCTTTATT ACAATTTTACAG-3', cGnRH-II: 5'-CAGCGAAGGA ACATCCTTAA-3') in $10 \mu \mathrm{l}$ of 
reaction mixture to prepare the first strand cDNA, diluted to $1: 10$, and used as the standards for quantitative real-time PCR assays.

Quantitative real-time PCRs were carried out with an ABI Prism 7700 Sequence Detection System (PE Applied Biosystems, Foster, CA, USA). The condition of PCR and nucleotide sequences of primers and fluorogenic probe (TaqMan probe, PE Applied Biosystems) for sGnRH mRNA was described previously (Onuma et al., 2005). For cGnRH-II mRNA, the sequences of primers were 5'-TGTGTCTGGGAGCCCAGCT-3' (forward) and 5'-CAGAGGTGGTAAATGAGTCCA-3' and that of probe was 5'-(Fam)-CTGGTCCCATGGCTGGTACCC-(Tamra)-3’ (TaqMan probe, PE Applied Biosystems). The PCR mixture $(10 \mu \mathrm{l})$ contained 1 x TaqMan buffer A (PE Applied Biosystems), $3.5 \mathrm{mM} \mathrm{MgCl}_{2}$, deoxynucleotide triphosphates (0.2 mM dATP, $0.2 \mathrm{mM} \mathrm{dCTP,}$ $0.2 \mathrm{mM}$ dGTP, and $0.2 \mathrm{mM}$ dUTP), $100 \mathrm{nM}$ of each forward and reverse primers, $150 \mu \mathrm{M}$ of fluorogenic probe, and $0.25 \mathrm{U}$ of AmpliTaq Gold polymerase (PE Applied Biosystems). Amplification was carried out at $95^{\circ} \mathrm{C}$ for $10 \mathrm{~min}$, for 40 cycles at $95^{\circ} \mathrm{C}$ for $15 \mathrm{sec}$, and $61^{\circ} \mathrm{C}$ for 45 sec.

\subsection{Assessment of assay methods}

In each assay, a standard sample (4 ng of chum salmon brain cDNA) was subjected to amplification in triplicate to estimate coefficients of variation (CVs) within and between assay runs. The ranges of intra-assay CVs were $0.9-15.8 \%$ for sGnRH mRNA and $2.1-14.7 \%$ for cGnRH-II mRNA. The inter assay CV was $9.5 \%$ for sGnRH mRNA and $16.5 \%$ for cGnRH-II mRNA. We confirmed that the single specific fragment was amplified in the present assay system, and the curves obtained from serially diluted chum salmon brain cDNA were parallel to the standard curves for cGnRH-II mRNA, which were linear within the ranges between $2 \times 10^{2}$ and $2 \times 10^{7}$ copies (Supplemental Fig. 1). Specificity of standard 
curves for sGnRH mRNA was assessed previously (Onuma et al., 2005). The present assay systems were thus satisfactory to determine absolute amounts of GnRH mRNAs in fresh frozen sections of the brain of chum salmon.

In the MT, where cGnRH-II neurons are localized (Amano et al., 1997), the absolute amounts of cGnRH-II mRNA were 10- to 500-fold those in other brain loci (Supplemental Fig. 2). The amounts of cGnRH-II in the anterior parts from the ROB to the PMG + NT were usually less than the detection limit of $2 \times 10^{2}$ copies/well (data not shown). In the present study, we thus only presented the amounts of cGnRH-II mRNA in the MT. The amounts of sGnRH mRNA were within detectable ranges in all examined brain loci, in accordance with our previous study (Onuma et al., 2005).

\subsection{Statistics}

The amounts of GnRH mRNAs were calculated as copies/ $\mu$ g total RNA, because the amounts of total RNA extracted from particular tissues were rather stable in our previous studies. Values were shown as mean \pm standard error of the mean. One or two abnormal values were removed from each group using Smirnov-Grubb’s test, when significant. Data from different sampling stations in the Gulf of Alaska or the Bering Sea were combined, because differences among fishing stations were not significant. Data from all ages of fish were pooled and treated as immature or maturing groups. One-way ANOVAs followed by a post-hoc Tukey's test was used to test for statistically significant differences among groups and sampling points.

\section{Results}

3.1. Changes in the amounts of GnRH mRNAs in discrete brain loci of oceanic chum salmon In general, the amounts of sGnRH mRNA were larger in the maturing adults in the Gulf 
of Alaska during February 2006 than those in the summer fish in the Bering Sea from June to July 2003. These seasonal differences between the winter fish in the Gulf of Alaska and the summer fish in the Bering Sea were observed in almost all of the examined brain loci.

In the males, the amounts of sGnRH mRNA in the $\mathrm{TN}$ of the maturing winter adults were more than 2-fold those of maturing summer adults (Fig. 2). In the females, the amounts of sGnRH mRNA in the ROB and OB of the winter fish were higher than those of the summer fish. The VT of the maturing winter males contained more than 2-fold amounts of sGnRH mRNA when compared with those in the summer Bering Sea (Fig. 3), whereas, in the females, seasonal difference in the amounts of sGnRH mRNA was observed in the PPa. In both sexes, the amounts of sGnRH mRNA in the PMp and PMm of the maturing winter adults in the Gulf of Alaska were 2- to 4-fold the maturing summer fish in the Bering Sea (Fig. 4). Similar seasonal difference was observed in the PMg and the NT of the females.

These seasonal differences were not observed in the amounts of sGnRH mRNA in the MT in both males and females (Fig. 4). Similarly, seasonal differences were not observed in the amounts of cGnRH-II mRNA in the MT, although those in the Bering fish were about 0.5-fold those of the maturing adults in the Gulf of Alaska.

In the Bering Sea, differences in the amounts of GnRH mRNAs were not apparent between the immature fish and the maturing adults (Fig. 5 and supplemental Fig. 3-4). The VT and PPa, where hypophysiotropic GnRH neurons are localized (Amano et al., 1997), did not show significant increases in the amounts of sGnRH mRNA in the maturing adults, except the PPa of the males in 2002 and the females in 2001 (Fig. 5). Significant differences between the immature fish and the maturing adults were also not observed in the $\mathrm{OB}$ and $\mathrm{TN}$, except in the ROB and $\mathrm{OB}$ of the females in 2002 (Supplemental Fig. 3). Similarly, differences between the immature fish and the maturing adults were not apparent in the posterior parts, although significant differences between the maturing adults I and the 
maturing adults II fish were found in the PMp and PMm of the males in 2001 and the PMg and NT of the females in 2001 (Supplemental Fig. 4). Similarly, differences were not significant in the amounts of cGnRH-II mRNA in the MT (Supplemental Fig. 4).

\subsection{Changes in the amounts of GnRH mRNAs in homing adults}

In the homing adults, the amounts of sGnRH mRNA increased in almost all the brain loci during upstream migration to the natal Ishikari River in 2002 and 2003, although the patterns of changes were not the same between the males and the females (Fig. 6-8). These increases in the amounts of sGnRH mRNA were coincident with the previous observations from 1997 to 1999 (Onuma et al., 2005).

In the males, the amounts of sGnRH mRNA in the OB attained a peak near the hatchery, while those in the TN increased during the last phase of migration from the midway to the hatchery in 2002 (Fig. 6). In the females, those in the COB decreased during migration from the NE coast of Hokkaido toward the midway of the river in 2003. In both sexes, the amounts of sGnRH mRNA in the VT and PPa tended to decrease during migration from the Bering Sea to the coastal areas, and then peaked from the midway through the natal hatchery in 2002 and 2003 (Fig. 7). The amounts of sGnRH mRNA in the VT and PPa thus increased in accordance with final maturation, as all of the present fish completed spermiation or ovulation at or near the hatchery (Onuma et al., 2009a).

In the males, the amounts of sGnRH mRNA in the PMg and NT decreased during migration from the Bering Sea to the estuary of the Ishikari River, followed by an increase at the fish wheel near the hatchery in 2003 (Fig. 8). In 2002, those in the MT showed a peak at the estuary of the Ishikari River. In the females, increases in the amounts of sGnRH mRNA during upstream migration were observed in the PMp and PMm, PMg and NT, and MT in 2002. In 2003, those in the PMp and PMm decreased during upstream migration from the 
coast to the estuary, followed by an increase during further migration to the hatchery.

The amounts of cGnRH-II mRNA in the MT increased during upstream migration in 2002 and 2003 (Fig. 9). In 2002, the amounts in the MT showed 10- to 20-fold elevation during migration from the Ishikari Bay to the estuary of the Ishikari River, followed by a decrease at the fish wheel near the hatchery. In 2003, the amounts of cGnRH-II mRNA in the males peaked at the fish wheel, followed by a decrease at the hatchery. In the females, the MT of fish at the NE coast of Hokkaido contained 3- to 4-fold amounts of cGnRH-II mRNA when compared to the maturing fish in the Bering Sea. Afterward, they decreased during upstream migration to the hatchery.

\section{Discussion}

In the present study, we examined gene expression for GnRHs in discrete brain loci of oceanic and homing chum salmon to address neuroendocrine events underlying the initiation of spawning migration. The most important finding is that the absolute amounts of sGnRH mRNA were significantly larger in the maturing adults in the winter Gulf of Alaska than those in the maturing adults in the summer Bering Sea. These seasonal differences were observed in almost all of the brain loci, indicating elevation of sGnRH gene expression in homing chum salmon early in the winter Gulf of Alaska. The present study provides the first evidence to support a possible involvement of neuropeptide in the onset of spawning migration.

A concern is that the fish in the Gulf of Alaska were sampled only in February 2006. Nonetheless, the seasonal difference in the amounts of sGnRH mRNA is likely to be reproducible, because the absolute amounts of sGnRH mRNA in the Bering chum salmon were within the same ranges in 2001, 2002 and 2003. The magnitudes of statistically significant differences in the amounts of sGnRH mRNA were much greater than the assay CVs of $0.9-15.8 \%$. The seasonal differences in the amounts of sGnRH mRNA are thus 
considerable to be not an artifactual result derived from differences in sampling seasons and years. The differences in the amounts of GnRH mRNAs were not due to changes in the size of brain, because they are not consistent with those in the body sizes (Onuma et al., 2009a). Reliability is further supported by our recent analysis showing that the amounts of preproghrelin-1 and preproghrelin-2 mRNAs showed different patterns in the same samples used in the present study (Onuma et al., in preparation). The present result is thus satisfactory to discuss changes in expression of GnRH genes in oceanic chum salmon prior to the onset of spawning migration.

The present pattern of seasonal difference in sGnRH gene expression coincides well with that in farmed masu salmon (Ando et al., 2001; Kitahashi et al., 2004). In the farmed fish, the amounts of sGnRH mRNA in the forebrain were already high in the pre-pubertal stage from winter to spring, declined toward summer, and again elevated in the spawning season. Since the maturing adults leave the Bering Sea for the natal river by the end of summer (Onuma et al., 2009a), gene expression for sGnRH should be increased several months prior to the initiation of homing behavior from the summer Bering Sea (see Fig. 10A).

\subsection{The HPG-axis activity during the initiation of spawning migration}

In the maturing summer adults, the amounts of sGnRH mRNA in the VT and PPa, where sGnRH neurons play roles in the control of the PG-axis (Amano et al., 1997), were significantly smaller than those in the maturing winter adults. Nonetheless, in the maturing summer adults, the pituitary amounts of GTH subunit mRNAs and the contents of FSH and LH in the summer fish were more than 10-fold those in the winter fish (Onuma et al., 2009a). Gene expression for sGnRH is thus likely to be elevated before the increase in the PG-axis activity of chum salmon in the summer Bering Sea (Fig. 10A). Furthermore, the present results showed that gene expression of sGnRH elevated in association with activation of the 
PG-axis during upstream migration in the breeding season in autumn (Fig. 10B). These changes coincide well with profiles of seasonal changes in the amounts of sGnRH mRNAs in the forebrain and the amounts of GTH subunit mRNAs in the pituitary of pond-reared masu salmon (Ando et al., 2001; Kitahashi et al., 2004), so that the regulatory mechanisms of the HPG-axis in oceanic chum salmon are considered to be similar to those found in farmed salmonid fish.

In salmonids, the activity of the PG-axis is regulated by sGnRH through season-dependent manners (Ando and Urano, 2005). Salmon GnRH directly elevated the amounts of GP $\alpha 2$ and FSH $\beta$ mRNAs in the pituitaries of maturing coho salmon in vitro from April to May (Dickey and Swanson, 2000). Such stimulatory effect of sGnRH alone was not apparent in pituitary cells of masu salmon in late-July and September (Ando et al., 2004). In masu salmon, the amounts of sGnRH peptide in the pituitary gradually increased with gonadal maturation from spring to autumn (Amano et al., 1992; Amano et al., 1993). The amounts of several subtypes of GnRH receptors (msGnRH-Rs) in the pituitary showed a transient peak from January to March (Jodo et al., 2005b). It is thus conceivable that the PG-axis is activated by sGnRH neurons when chum salmon migrate from the Gulf of Alaska to the Bering Sea from winter through spring.

At present, information on factors which regulate gene expression for GnRH in the present chum salmon is not sufficient. Highly probable factors are sex steroid hormones, because the plasma levels of $\mathrm{T}, 11 \mathrm{KT}$ and $\mathrm{E} 2$ in the maturing adults are higher than $10 \mathrm{nM}$ (Onuma et al., 2009a). These circulating levels are sufficiently higher than the reported values of equilibrium dissociation constants for androgen and estrogen receptors in the teleost brain (Pasmanik and Callard, 1988; Allison and Omeljaniuk, 2000). Administration of androgens and estrogens actually modulated the amounts of sGnRH mRNA in the preoptic area of masu salmon (Amano et al., 1994) and the forebrain of rainbow trout (Vetillard et al., 
2006).

Sex steroid hormones and sGnRH synergistically stimulate GTH syntheses in the salmonid pituitary during the period of early gametogenesis (Ando and Urano, 2005). In masu salmon, a treatment of primary pituitary cells with sGnRH and E2 increased the amounts of LH $\beta$ mRNA and the releases of FSH and LH in May (Ando et al., 2004). In March and May, a single treatment of masu salmon pituitary cells with sGnRH, T or E2 elevated expression of genes for salmon fushi tarazu factor 1 homolog (sFF1-I) and estrogen receptor (ER) $\alpha$ (Onuma et al., 2007), which directly activated the salmon LH $\beta$ promoter (Le Drean et al., 1996). Such stimulatory effects are attenuated after the late stages of gametogenesis in late July (Ando et al., 2004; Onuma et al., 2007). These facts suggest that brain sGnRH neurons and pituitary GTH cells are up-regulated by circulating sex steroid hormones from winter to early summer, when chum salmon initiate spawning migration from the Bering Sea.

An important question here is humoral factors that elevate activity of the HPG-axis and enable oceanic chum salmon to determine whether to initiate puberty or not to mature. Our recent studies indicate that IGF-I, a hepatic polypeptide that acts as a mediator of growth-promoting action of growth hormone (GH) in teleosts (Duan and Hirano, 1992), is such a factor. The plasma level of IGF-I increased with body growth during winter and spring. This seasonal increase was linked to initiation of gametogenesis in male chinook salmon (Campbell et al., 2003) and female coho salmon (Campbell et al., 2006). It is also true in the present chum salmon, because the plasma level of IGF-I in the maturing adults were 2- to 3-fold those in the immature fish (Onuma et al., 2009b; Onuma et al., 2010a). The amounts of GH mRNA in the pituitary in the maturing summer fish were significantly larger than those in the winter fish (Onuma et al., 2010b). In addition, IGF-I potentiated sGnRH-stimulated release of FSH and LH from pituitary cells of rainbow trout (Weil et al., 
1999) and coho salmon (Baker et al., 2000) from January to April, and counteracted sGnRH-stimulated gene expression for FSH $\beta$ and $\mathrm{LH} \beta$ in pituitary cells of masu salmon in April (Ando et al., 2006). In masu salmon, IGF-I itself stimulated synthesis and release of FSH and LH during early stage of gametogenesis in February (Furukuma et al., 2008). Direct action of IGF-I to the GnRH neurons is also plausible because $\left[{ }^{125} \mathrm{I}\right] \mathrm{IGF}-\mathrm{I}$ infused into the cardiac artery of adult rats was delivered into the hypothalamus by crossing the blood brain-barrier (Reinhardt and Bondy, 1994).

\subsection{GnRH and migratory behavior}

The seasonal differences in the amounts of sGnRH mRNA were observed in the OB, TN, PM and MT. The amounts of sGnRH and cGnRH-II mRNAs increased in these brain loci during upstream migration of homing adults. In teleosts, GnRH neurons in these brain loci send fibers throughout the brain, but considered not to send fibers to the pituitary (Bushnik and Fernald, 1995; Yamamoto et al., 1998). Therefore, the present results can be regarded as evidence that gene expression for GnRHs in the brain changed in association with migratory behavior as well as control of the PG-axis activity.

A line of evidence suggests that GnRHs regulate behavior by modulating the sensory systems. Application of GnRHs increased excitability of olfactory receptor neurons (Eisthen et al., 2000), retinal cells (Walker and Stell, 1986) and preoptic neurosecretory neurons (Saito et al., 2003), and fascilitated synaptic transmission of retinotectal neurons (Kinoshita et al., 2007). An importance of GnRHs in neuronal control of migratory behavior was underscored by the facts that administration of $\mathrm{GnRH}$ analog into the dorsal muscle of pre-spawning sockeye salmon (Kitahashi et al., 1998b) and chum salmon (Kitahashi et al., 2001) shortened the duration of homing behavior to the natal hatchery.

Our recent studies suggest involvements of sGnRH in neuroendocrine control of FW 
adaptation. An application of sGnRH directly elevated activities of neurohypophysial hormone producing neurons, which are involved in control of osmoregulation and reproductive behavior (Urano et al., 1994), in the brain preparation of pre-spawning chum salmon in the Ishikari bay (Abe and Urano, 2005). In pre-spawning masu salmon, an application of sGnRH elevated the amounts of prolactin (PRL), a FW adaptation hormone (Hirano et al., 1987), in pituitary cells in vitro (Onuma et al., 2005). In the present chum salmon, the amounts of PRL mRNA elevated in the pituitaries prior to their homing behavior from the summer Bering Sea, and kept the elevated levels until their arrival to the Ishikari River (Onuma et al., 2010b). Behaviorally, intraventricular injection of sGnRH to pre-spawning chum salmon stimulated a preference of FW in an aquarium that allowed fish to migrate between SW and FW steams (Kitahashi et al., 2001). In combination with the present results, we speculate that sGnRH neurons modulate activity of salt and water homeostasis, and facilitate oceanic chum salmon to migrate into the natal river.

In farmed masu salmon, seasonal changes in the amounts of sGnRH mRNAs in the forebrain (Ando et al., 2001; Kitahashi et al., 2004) corresponded well with the contents of sGnRH peptide in the olfactory bulb, telencephalon and hypothalamus (Amano et al., 1992; Amano et al., 1993). They retained at high levels from winter to spring, followed by the decrease toward summer. We thus consider that peptide contents of sGnRH correlated with the amounts of sGnRH mRNAs in oceanic chum salmon. Winter chum salmon may have already stored sGnRH in almost all the brain loci, and released it into the brain and the pituitary until their arrival at the summer Bering Sea. Such synthesis and release of sGnRH may be controlled by stimulatory upstream neuropeptides, such as kisspeptin/metastin (Popa et al., 2008).

The amounts of cGnRH-II mRNA in the MT peaked during upstream migration in the breeding season (Fig. 10B). However, the increase in the amounts of cGnRH-II peptide was 
not apparent in masu salmon during gonadal maturation (Amano et al., 1992; Amano et al., 1993). Despite this discrepancy, several reports showed that cGnRH-II directly changed neuronal activity in the salmonid brain. In the brains of rainbow trout, cGnRH-II increased electric activity of magnocellular neurosecretory neurons in a GnRH-R dependent manner (Saito et al., 2003), and facilitated synaptic transmission of retinotectal neurons (Kinoshita et al., 2007). Intraventricular injection of cGnRH-II induced spawning behavior (Volkoff and Peter, 1999), and inhibited feeding behavior (Matsuda et al., 2008) of goldfish. The amounts of cGnRH-II mRNA in the midbrain were increased when spawning behavior was artificially induced by an injection with prostaglandin (Canosa et al., 2008). These findings support an idea that cGnRH-II neurons are involved in upstream migration and/or reproductive behavior.

Urano et al. (1999) hypothesized that reproductive phenomena underlying spawning migration are coordinated by neuroendocrine cells such as GnRH neurons, which have appropriate anatomical feature to coordinate functions of the PG-axis and the central nervous system. Our present results are not contradictory to this hypothesis. The seasonal difference in the amounts of sGnRH mRNAs in the oceanic chum salmon is likely to reflect changes in activity of sGnRH neurons prior to the onset of spawning migration from the summer Bering Sea. However, there is still a paucity of information concerning when, where and how target neurons respond to GnRH. In the forebrain of masu salmon, the amounts of msGnRH-R mRNAs decreased from winter to summer, followed by an increase in the spawning season in autumn (Jodo et al., 2005a). Future investigation of GnRH-Rs in discrete brain loci are required to clarify molecular and physiological mechanisms that sensitize targets of GnRH neurons which respond more robustly to GnRH-stimulation for motivation of homing behavior.

In conclusion, gene expression for sGnRH was elevated when chum salmon are migrating from the winter Gulf of Alaska to the summer Bering Sea. The present results 
suggest that sGnRH neurons are activated in almost all the brain loci for initiation of gonadal maturation and homing behavior.

\section{Acknowledgments}

The authors thank our colleagues in Hokkaido University, Mr. H. Aihara (Atsuta fisherman's cooperative association) and crews of R/V Wakatake-maru, Kaiyo-maru and Hokusei-maru for their help in sampling of chum salmon. The present study was supported in part by the Grants-in-Aid from the Fisheries Agency and the Ministry of Education, Culture, Sports, Science and Technology, Japan. T.A.O. was supported by a research fellowship from the Japanese Society for the Promotion of Science for Young Scientists (No. 200409104 and 200609320). Ocean researches were supported in part by the Promotion Program for International Resources Surveys from the Fisheries Agency of Japan. 


\section{References}

Allison, C.M., ,Omeljaniuk, R. J., 2000. Binding characteristics of $\left[{ }^{3} \mathrm{H}\right] 17$ beta-estradiol in the hypothalamus of juvenile rainbow trout, Oncorhynchus mykiss.

Comp. Biochem. Physiol. C 126, 321-332.

Amano, M., Aida, K., Okumoto, N., Hasegawa, Y., 1992. Changes in salmon GnRH and chicken GnRH-II contents in the brain and pituitary, and GTH contents in the pituitary in female masu salmon, Oncorhynchus masou, from hatching through ovulation. Zool. Sci. 9, 375-386.

Amano, M., Aida, K., Okumoto, N., Hasegawa, Y., 1993. Changes in levels of GnRH in the brain and pituitary and GTH in the pituitary in male masu salmon, Oncorhynchus masou, from hatching to maturation. Fish Physiol. Biochem. 11, 233-240.

Amano, M., Ashihara, M., Yoshiura, Y., Kitamura, S., Ikuta, K., Aida, K., 1998. Two differing salmon GnRH precursor mRNAs are co-expressed in the brain of sockeye salmon. Cell Tissue Res. 292, 267-273.

Amano, M., Hyodo, S., Urano, A., Okumoto, N., Kitamura, S., Ikuta, K., Suzuki, Y., Aida, K., 1994. Activation of salmon gonadotropin-releasing hormone synthesis by $17 \alpha$-methyitestosterone administration in yearling masu salmon, Oncorhynchus masou. Gen. Comp. Endocrinol. 95, 374-380.

Amano, M., Urano, A., Aida, K., 1997. Distribution and function of gonadotropin-releasing hormone (GnRH) in the teleost brain. Zool. Sci. 14, 1-11.

Ando, H., Sasaki, Y., Okada, H., Urano, A., 2001. Prepubertal increases in the levels of two salmon gonadotropin-releasing hormone mRNAs in the ventral telencephalon and preoptic 
area of masu salmon. Neurosci. Lett. 307, 93-96.

Ando, H., Swanson, P., Kitani, T., Koide, N., Okada, H., Ueda, H., Urano, A., 2004. Synergistic effects of salmon gonadotropin-releasing hormone and estradiol-17 $\beta$ on gonadotropin subunit gene expression and release in masu salmon pituitary cells in vitro. Gen. Comp. Endocrinol. 137, 109-121.

Ando, H., Urano, A., 2005. Molecular regulation of gonadotropin secretion by gonadotropin-releasing hormone in salmonid fishes. Zool. Sci. 22, 379-389.

Ando, H., Luo, Q., Koide, N., Okada, H., Urano, A., 2006. Effects of insulin-like growth factor I on GnRH-induced gonadotropin subunit gene expressions in masu salmon pituitary cells at different stages of sexual maturation. Gen. Comp. Endocrinol. 149, 21-29.

Ashihara, M., Suzuki, M., Kubokawa, K., Yoshiura, Y., Kobayashi, M., Urano, A., Aida, K., 1995. Two differing precursor genes for the salmon-type gonadotropin-releasing hormone exist in salmonids. J. Mol. Endocrinol. 15, 1-9.

Baker, D.M., Davies, B., Dickhoff, W. W., Swanson, P., 2000. Insulin-like growth factor I increases follicle-stimulating hormone (FSH) content and gonadotropin-releasing hormone-stimulated FSH release from coho salmon pituitary cells in vitro.

Biol. Reprod. 63, 865-871.

Bushnik, T.L., Fernald, R. D., 1995. The population of GnRH-containing neurons showing socially mediated size changes project to the pituitary in a teleost, Haplochromis burtoni. Brain Behav. Evol. 46, 371-377.

Bustin, S.A., 2000. Absolute quantification of mRNA using real-time reverse transcription polymerase chain reaction assays. J. Mol. Endocrinol. 25, 169-193. 
Campbell, B., Dickey, J., Beckman, B., Young, G., Pierce, A., Fukada, H., Swanson, P., 2006. Previtellogenic oocyte growth in salmon: relationships among body growth, plasma insulin-like growth factor-1, estradiol-17beta, follicle-stimulating hormone and expression of ovarian genes for insulin-like growth factors, steroidogenic-acute regulatory protein and receptors for gonadotropins, growth hormone, and somatolactin. Biol. Reprod. 75, 34-44.

Campbell, B., Dickey, J. T., Swanson, P., 2003. Endocrine changes during onset of puberty in male spring Chinook salmon, Oncorhynchus tshawytscha. Biol Reprod 69, 2109-2117.

Canosa, L.F., Stacey, N., Peter, R. E., 2008. Changes in brain mRNA levels of gonadotropin-releasing hormone, pituitary adenylate cyclase activating polypeptide, and somatostatin during ovulatory luteinizing hormone and growth hormone surges in goldfish. Am. J. Physiol. Regul. Integr. Comp. Physiol. 295, R1815-R1821.

Chirgwin, J.M., Przybyla, A. E., MacDonald, R. J., Rutter, W. J., 1979. Isolation of biologically active ribonucleic acid from sources enriched in ribonuclease. Biochemistry 24, 5294-5299.

Davis, N.D., Myers, K. W., Walker, R. V., Harris, C. K., 1990. The Fisheries Research Institute's high seas salmonid tagging program and methodology for scale pattern analysis. Amer. Fish Soc. Symp. 7, 863-879.

Dickey, J.T.,,Swanson, P., 2000. Effects of salmon gonadotropin-releasing hormone on follicle stimulating hormone secretion and subunit gene expression in coho salmon (Oncorhynchus kisutch). Gen. Comp. Endocrinol. 118, 436-449.

Duan, C., Hirano, T., 1992. Effects of insulin-like growth factor-I and insulin on the in-vitro uptake of sulphate by eel branchial cartilage: Evidence for the presence of independent 
hepatic and pancreatic sulphation factors. J. Endocrinol. 133, 211-219.

Eisthen, H.L., Delay, R.J., Wirsig-Wiechmann, C.R., Dionne, V.E., 2000. Neuromodulatory effects of gonadotropin releasing hormone on olfactory receptor neurons. J. Neurosci. 20, 3947-3955.

Furukuma, S., Onuma, T., Swanson, P., Luo, Q., Koide, N., Okada, H., Urano, A., Ando, H., 2008. Stimulatory effects of insulin-like growth factor 1 on expression of gonadotropin subunit genes and release of follicle-stimulating hormone and luteinizing hormone in masu salmon pituitary cells early in gametogenesis. Zool. Sci. 25, 88-98.

Higa, M., Kitahashi, T., Sasaki, Y., Okada, H., Ando, H., 1997. Distinct promoter sequences of two precursor genes for slamon gonadotropin-releasing hormone in masu salmon. J. Mol. Endocrinol. 19, 149-161.

Jodo, A., Kitahashi, T., Taniyama, S., Bhandari, R. K., Ueda, H., Urano, A., Ando, H., 2005a. Seasonal variation in the expression of five subtypes of gonadotropin-releasing hormone receptor genes in the brain of masu salmon from immaturity to spawning. Zool. Sci. 22, 1331-1338.

Jodo, A., Kitahashi, T., Taniyama, S., Ueda, H., Urano, A., Ando, H., 2005b. Seasonal changes in expression of genes encoding five types of gonadotropin-releasing hormone receptors and responses to GnRH analog in the pituitary of masu salmon. Gen. Comp. Endocrinol. 144, 1-9.

Kinoshita, M., Kobayashi, S., Urano, A., Ito, E., 2007. Neuromodulatory effects of gonadotropin-releasing hormone on retinotectal synaptic transmission in the optic tectum of rainbow trout. Eur. J. Neurosci. 25, 480-484.

Kitahashi, T., Ando, H., Ban, M., Ueda, H., Urano, A., 1998a. Changes in the levels of 
gonadotropin subunit mRNAs in the pituitary of pre-spawning chum salmon.

Zool. Sci. 15, 753-760.

Kitahashi, T., Sato, A., Alok, D., Kaeriyama, M., Zohar, Y., Yamauchi, K., Urano, A., Ueda, H., 1998b. Gonadotropin-releasing hormone analog and sex steroids shorten homing duration of sockeye salmon in Lake Shikotsu. Zool. Sci. 15, 767-771.

Kitahashi, T., Ando, H., Urano, A., Ban, M., Saito, S., Tanaka, H., Naito, Y., Ueda, H., 2000. Micro data logger analyses of homing behavior of chum salmon in Ishikari bay. Zool. Sci. 17, 1247-1253.

Kitahashi, T., Takagi, Y., Ban, M., Ando, H., Ueda, H., Urano, A., 2001. Effects of GnRHa administration on upstream migration of homing chum salmon.

Proc. Japan Soc. Comp. Endocrinol. 16, pp. 11.

Kitahashi, T., Bhandari, R. K., Taniyama, S., Ando, H., Ueda, H., Urano, A., 2004. Changes in expression of salmon GnRH genes and responsiveness of pituitary hormone genes to GnRH analog during growth and sexual maturation in masu salmon. In: Oishi T., Tsutsui K., Tanaka S. and Kikuyama S. (Eds.), Trends in Comparative Endocrinology, Proc. Fifth Cong. Asia and Oceania Soc. for Comp. Endocrinol. pp. 92-94.

Le Drean, Y., Liu, D., Wong, A. O., Xiong, F., Hew, C. L., 1996. Steroidogenic factor 1 and estradiol receptor act in synergism to regulate the expression of the salmon gonadotropin II beta subunit gene. Mol. Endocrinol. 10, 217-229.

Makino, K., Onuma, T. A., Kitahashi, T., Ando, H., Ban, M., Urano, A., 2007. Expression of hormone genes and osmoregulation in homing chum salmon: A minireview. Gen. Comp Endocrinol. 
Matsuda, K., Nakamura, K., Shimakura, S., Miura, T., Kageyama, H., Uchiyama, M., Shioda, S., Ando, H., 2008. Inhibitory effect of chicken gonadotropin-releasing hormone II on food intake in the goldfish, Carassius auratus. Horm. Behav. 54, 83-89.

Moriya, S., Urawa, S., Suzuki, O., Urano, A., Abe, S., 2004. DNA microarray for rapid detection of mitochondrial DNA haplotypes of chum salmon.

Mar. Biotechnol. (NY) 6, 430-434.

Moriya, S., Sato, S., Azumaya, T., Suzuki, O., Urawa, S., Urano, A., Abe, S., 2007. Genetic stock identification of chum salmon in the bering sea and north pacific ocean using mitochondrial DNA microarray. Mar. Biotechnol. (NY) 9, 179-191.

Okubo, K, Nagahama, Y., 2008, Structural and functional evolution of gonadotropinreleasing hormone in vertebrates. Acta. Physiol. 193, 3-15

Onuma, T., Higashi, Y., Ando, H., Ban, M., Ueda, H., Urano, A., 2003a. Year-to-year differences in plasma levels of steroid hormones in pre-spawning chum salmon.

Gen. Comp. Endocrinol. 133, 199-215.

Onuma, T., Kitahashi, T., Taniyama, S., Saito, D., Ando, H., Urano, A., 2003b. Changes in expression of genes encoding gonadotropin subunits and growth hormone/prolactin/somatolactin family hormones during final maturation and freshwater adaptation in prespawning chum salmon. Endocrine 20, 23-34.

Onuma, T., Higa, M., Ando, H., Ban, M., Urano, A., 2005. Elevation of gene expression for salmon gonadotropin-releasing hormone in discrete brain loci of prespawning chum salmon during upstream migration. J. Neurobiol. 63, 126-145.

Onuma, T.A., Ando, H., Koide, N., Okada, H., Urano, A., 2007. Reproductive stage-related 
effects of salmon GnRH and sex steroid hormones on expression of genes encoding fushi tarazu factor 1 homolog and estrogen receptor alpha in masu salmon pituitary cells in vitro. Gen. Comp. Endocrinol. 152, 64-72.

Onuma, T.A., Sato, S., Katsumata, H., Makino, K., Hu, W., Jodo, A., Davis, N. D., Dickey, J. T., Ban, M., Ando, H., Fukuwaka, M., Azumaya, T., Swanson, P., Urano, A., 2009a. Activity of the pituitary-gonadal axis is increased prior to the onset of spawning migration of chum salmon. J. Exp. Biol. 212, 56-70.

Onuma, T.A., Makino, K., Ban, M., Ando, H., Fukuwaka, M., Azumaya, T., Swanson, P., Urano, A., 2009b. Elevation of the plasma level of insulin-like growth factor-I with reproductive maturation prior to initiation of spawning migration of chum salmon. Ann. N.Y. Acad. Sci. 1163: 497-500.

Onuma, T.A., Makino K., Katsumata H., Beckman B.R., Ban M., Ando H., Fukuwaka M., Azumaya T., Swanson P., Urano A., 2010a. Changes in the plasma levels of insulin-like growth factor-I from the onset of spawning migration through upstream migration in chum salmon. Gen. Comp. Endocrinol. 165: 237-243.

Onuma, T. A., Ban, M., Makino, K., Katsumata, H., Hu W., Ando H., Fukuwaka M., Azumaya T., Urano A., 2010b. Changes in gene expression for GH/PRL/SL family hormones in the pituitaries of homing chum salmon during ocean migration through upstream migration. Gen. Comp. Endocrinol. in press.

Pasmanik, M., ,Callard, G. V., 1988. A high abundance androgen receptor in goldfish brain: characteristics and seasonal changes. Endocrinology 123, 1162-1171.

Popa, S.M., Clifton, D. K., Steiner, R. A., 2008. The role of kisspeptins and GPR54 in the 
neuroendocrine regulation of reproduction. Annu. Rev. Physiol 70, 213-238.

Reinhardt, R.R., Bondy, C. A., 1994. Insulin-like growth factors cross the blood-brain barrier. Endocrinology 135, 1753-1761.

Rissman, E.F., 1996. Behavioral regulation of gonadotropin-releasing hormone. Biol Reprod 54, 413-419.

Saito, D., Ota, Y., Hiraoka, S., Hyodo, S., Ando, H., Urano, A., 2001. Effect of oceaographic environments on sexual maturation, salinity tolerance, and vasotocin gene expression in homing chum salmon. Zool. Sci. 18, 389-396.

Saito, D., Hasegawa, Y., Urano, A., 2003. Gonadotropin-releasing hormones modulate electrical activity of vasotocin and isotocin neurons in the brain of rainbow trout. Neurosci. Lett. 351, 107-110.

Salo, E. O., 1991. Life history of chum salmon (Oncorhynchus keta). In: Groot C. and Margolis L. (Eds.), Pacific Salmon Life Histories., Columbia Press, Vancouver, pp. 231-309.

Sanger, F., Nicklen, S., Coulson, A. R., 1977. DNA sequencing with chain-terminating inhibitors. Proc. Natl. Acad. Sci. USA 74, 5463-5467.

Sato, S., Kojima, H., Ando, J., Ando, H., Wilmot, RL., Seeb, LW., Efemov, V., LeClair, L., Buchholz, W., Jin, D., Urawa, S., Kaeriyama, M., Urano, A., Abe, S., 2004. Genetic population structure of chum salmon in the pacific rim inferred from mitochondrial DNA sequences variation. Environ. Biol. Fishes 69, 37-50.

Sato, S., S. Takahashi, L.W. Seeb, J.E. Seeb, F. Fukuwaka, S. Urawa, 2006. Stock Identification of Winter Chum Salmon by mitochondrial DNA and SNP Analyses. NPAFC 
Doc. 963.

Sato, S., Azumaya, T., Urawa, S., 2007. Genetic stock identification of chum salmon in the summer Bering Sea 2004. NPAFC Technical Report 7 , 66-68.

Suzuki, M., Hyodo, S., Kobayashi, M., Aida, K., Urano, A., 1992. Characterization and localization of mRNA encoding the salmon-type gonadotrophin-releasing hormone precursor of the masu salmon. J. Mol. Endocrinol. 9, 73-82.

Tanaka, H., Naito, Y., Davis, N. D., Urawa, S., Ueda, H., Fukuwaka, M., 2005. First Record of the at-sea swimming speed of a Pacifc salmon during its oceanic migration. Mar. Eco. Prog. Ser. 291, 307-312.

Urano A., Ando H., Ueda H., 1999. Molecular neuroendocrine basis of spawning migration in salmon. In: Kwon H. B., Joss J. M. P. and Ishii S. (Eds.), Recent Progress in Molecular and Comparative Endocrinology. Hormone Research Center, Kwangju, pp. 46-56.

Urawa S., 2000. Ocean migration route of Japanese chum salmon with a reference to future salmon research. NASRCR Newslet. 5: 3-9 (in Japanese).

Vetillard, A., Ferriere, F., Jego, P., Bailhache, T., 2006. Regulation of salmon gonadotrophin-releasing hormone gene expression by sex steroids in rainbow trout brain. J. Neuroendocrinol. 18, 445-453.

Volkoff, H., ,Peter, R. E., 1999. Actions of Two Forms of Gonadotropin Releasing Hormone and a GnRH Antagonist on Spawning Behavior of the Goldfish Carassius auratus. Gen. Comp. Endocrinol. 116, 347-355.

Von Schalburg, K. R.,Harrower, W. L., Sherwood, N. M., 1999. Regulation and expression of 
gonadotropin-releasing hormone in salmon embryo and gonad.

Mol. Cell Endocrinol. 157, 41-54.

Walker, S.E., Stell, W.K., 1986. Gonadotropin-releasing hormone (GnRF), molluscan cardioexcitatory peptide (FMRFamide), enkephalin and related neuropeptides affect goldfish retinal ganglion cell activity. Brain Res. 384, 262-273.

Weil, C., Carre, F., Blaise, O., Breton, B., Le Bail, P. Y., 1999. Differential effect of insulin-like growth factor I on in vitro gonadotropin (I and II) and growth hormone secretions in rainbow trout (Oncorhynchus mykiss) at different stages of the reproductive cycle.

Endocrinology 140, 2054-2062.

Yamamoto, N., Parhar, I. S., Sawai, N., Oka, Y., Ito, H., 1998. Preoptic gonadotropin-releasing hormone $(\mathrm{GnRH})$ neurons innervate the pituitary in teleosts. Neurosci. Res. 31, 31-38. 


\section{Figure legends}

Figure 1 The loci of brain where total RNA was extracted to determine the amounts of GnRH mRNAs (see Onuma et al., 2005 for detail). (A) A sagittal view of the discrete brain loci. The frozen brains were cut into $25-\mu$ m-thick serial transverse sections from the rostral part of olfactory bulb (OB) through the saccus vasculosus (SV) by use of a cryostat. Every tenth sections were Nissl-stained to ascertain the exact locus of cutting place, and the other sections were separated into nine loci: 1 , rostral OB (ROB) including the olfactory nerve; 2, OB; 3, caudal part of OB (COB) that contains the stratum granulare; 4, TN; 5, VT; 6, PPa; 7, PM pars parvocellularis (PMp) and PM pars magnocellularis (PMm); 8, PM pars gigantocellularis (PMg) and infundibular region including the nucleus tuberis (NT); 9, mesencephalic region including MT. The numbers correspond to the loci of brains shown in Supplemental Fig. 3. Distribution of sGnRH and cGnRH-II neuronal somata is shown as circles and squares, respectively. POA, preoptic area. (B) Photomicrographs of the representative transverse sections of the loci of forebrain. a-h correspond to planes shown in A. ca, commisura anterior; ent, nucleus entopeduncularis; nat, nucleus anterior tuberis; nlt, nucleus lateralis tuberis; OB, olfactory bulb; ON, olfactory nerve; Stgr, stratum granulare; tolm, tractus olfactorius medialis; $\mathrm{Vd}$, area ventralis telencephali pars dorsalis. Scale bar $=1$ $\mathrm{mm}$.

Figure 2 Amounts of sGnRH mRNA in the OB and TN of winter chum salmon in the Gulf of Alaska and summer chum salmon in the central Bering Sea. The ROB, OB, COB and TN correspond to the brain loci shown in Fig. 1. Fish in the Gulf of Alaska were collected in February 2006, and divided into immature fish and maturing adult I fish on the basis of histological features of gonads. Data from the winter chum salmon were compared with those from the maturing adult I fish in the Bering Sea in 2003. They are a portion of the fish 
used in Onuma et al. (2009a). The number of fish was 6-10 in each group. Each value represents mean \pm standard error. Significant differences among groups are identified with different letters ( $\mathrm{p}<0.05$ one-way ANOVA and Tukey’s test).

Figure 3 Amounts of sGnRH mRNA in the VT and PPa of winter chum salmon in the Gulf of Alaska and summer chum salmon in the central Bering Sea. The VT and PPa correspond to the brain loci shown in Fig. 1. Fish in the Gulf of Alaska were collected in February 2006, and divided into immature fish and maturing adult I fish on the basis of histological features of gonads. Data from the winter chum salmon were compared with those from the maturing adult I fish in the Bering Sea in 2003. They are a portion of the fish used in Onuma et al. (2009a). The number of fish was 6-10 in each group. Each value represents mean \pm standard error. Significant differences among groups are identified with different letters $(\mathrm{p}<$ 0.05 one-way ANOVA and Tukey’s test).

Figure 4 Amounts of sGnRH mRNA in the PM, NT and MT and amounts of cGnRH-II mRNA in the MT of winter chum salmon in the Gulf of Alaska and summer chum salmon in the central Bering Sea. The PMp + PMm, PMg + NT and MT correspond to the brain loci shown in Fig. 1. Fish in the Gulf of Alaska were collected in February 2006, and divided into immature fish and maturing adult I fish on the basis of histological features of gonads. Data from the winter chum salmon were compared with those from the maturing adult I fish in the Bering Sea in 2003. They are a portion of the fish used in Onuma et al. (2009a). The number of fish was 6-10 in each group. Each value represents mean \pm standard error. Significant differences among groups are identified with different letters $(p<0.05$ one-way ANOVA and Tukey's test). 
Figure 5 Amounts of sGnRH mRNA in the VT and PPa of chum salmon in the central Bering Sea 2001-2003. The VT and PPa correspond to the brain loci shown in Fig. 1. Fish were divided into immature fish and maturing adult I and II, as shown in the inset. They are a portion of the fish used in Onuma et al. (2009a). The number of fish was 5-10 in each group. Each value represents mean \pm standard error. Significant differences among groups are identified with different letters ( $\mathrm{p}<0.05$ one-way ANOVA and Tukey’s test).

Figure 6 Changes in the amounts of sGnRH mRNA in the OB and TN of homing adults during upstream migration in 2002 and 2003. The ROB, OB, COB and TN correspond to the brain loci shown in Fig. 1. Pre-spawning and matured chum salmon were collected along their homing pathway from the coast to the hatchery. Fish near or at the hatchery almost completed final maturation, so that they were regarded as matured adults. They are a portion of the fish used in Onuma et al. (2009a). The number of fish was 3-6 in each group. Each value represents mean \pm standard error. Significant differences among groups are identified with different letters ( $\mathrm{p}<0.05$ one-way ANOVA and Tukey’s test).

Figure 7 Changes in the amounts of sGnRH mRNA in the VT and PPa of homing adults during upstream migration in 2002 and 2003. The VT and PPa correspond to the brain loci shown in Fig. 1. Pre-spawning and matured chum salmon were collected along their homing pathway from the coast to the hatchery. Fish near or at the hatchery almost completed final maturation, so that they were regarded as matured adults. They are a portion of the fish used in Onuma et al. (2009a). The number of fish was 3-6 in each group. Each value represents mean \pm standard error. Significant differences among groups are identified with different letters ( $\mathrm{p}<0.05$ one-way ANOVA and Tukey’s test). 
Figure 8 Changes in the amounts of sGnRH mRNA in the PM, NT and MT of homing adults during upstream migration in 2002 and 2003. The PMp + PMm, PMg + NT and MT correspond to the brain loci shown in Fig. 1. Pre-spawning and matured chum salmon were collected along their homing pathway from the coast to the hatchery. Fish near or at the hatchery almost completed final maturation, so that they were regarded as matured adults. They are a portion of the fish used in Onuma et al. (2009a). The number of fish was 3-6 in each group. Each value represents mean \pm standard error. Significant differences among groups are identified with different letters ( $\mathrm{p}<0.05$ one-way ANOVA and Tukey’s test).

Figure 9 Changes in the amounts of cGnRH-II mRNA in the MT of homing adults during upstream migration in 2002 and 2003. Pre-spawning and matured chum salmon were collected along their homing pathway from the coast to the hatchery. Fish near or at the hatchery almost completed final maturation, so that they were regarded as matured adults. They are a portion of the fish used in Onuma et al. (2009a). The number of fish was 3-6 in each group. Each value represents mean \pm standard error. Significant differences among groups are identified with different letters ( $\mathrm{p}<0.05$ one-way ANOVA and Tukey's test).

Figure 10 A summary of changes in the HPG-axis of maturing chum salmon prior to and during spawning migration. (A) The amounts of sGnRH mRNAs peaked in discrete loci of the forebrain during migration from the winter Gulf of Alaska through the summer Bering Sea. As a result, the amounts of sGnRH mRNA in the summer fish were significantly lower than those in the winter fish. Such changes in gene expression for sGnRH were triggered before elevation of the parameters of the PG-axis activity, such as GTH subunit mRNAs, contents of FSH and LH in the pituitary, and the plasma levels of sex steroid hormones (Onuma et al., 2009a). (B) The amounts of sGnRH and cGnRH-II mRNAs elevated in discrete brain loci 
during upstream migration in the breeding period. Such elevation of gene expression for GnRH occurred coincidently with elevation of the LH $\beta$ mRNA and LH in the pituitary and

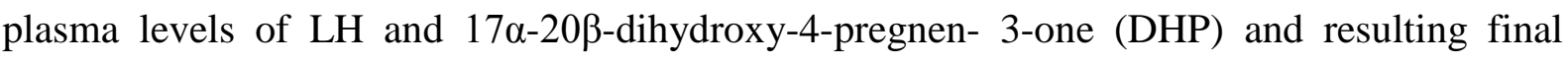
maturation of gonads (Onuma et al., 2003a; Onuma et al., 2005; Onuma et al., 2009a).

Supplemental Figure 1 Standard curves for quantitative real-time PCR for cGnRH-II mRNA. Reverse transcribed standard RNA (filled circle) or brain total RNA (unfilled circle) was amplified. The standard curves were linear within the ranges of $2 \times 10^{2}$ to $2 \times 10^{7}$ copies, so that detection limit was $2 \times 10^{2}$ copies/well. Serially diluted total RNAs were parallel to the standard RNAs. Specificity of primers was confirmed by use of standard cDNAs and chum salmon brain cDNAs as templates (inset picture).

Supplemental Figure 2 Comparison of the absolute amounts of cGnRH-II mRNAs in the examined brain loci of chum salmon captured in the Bering Sea in 2002. The numbers represent following regions: 1 , rostral $\mathrm{OB}(\mathrm{ROB})$ including the olfactory nerve; 2 , OB; 3 , caudal part of OB (COB) that contains the stratum granulare; 4, TN; 5, VT; 6, PPa; 7, PM pars parvocellularis (PMp) and PM pars magnocellularis (PMm); 8, PM pars gigantocellularis (PMg) and infundibular region including nucleus tuberis (NT); 9, mesencephalic region including MT. Values are mean \pm standard error $(n=6-9)$. Note that the amounts of sGnRH-II mRNA in the MT were more than 10- to 500-fold those in other brain loci.

Supplemental Figure 3 Amounts of sGnRH mRNA in the OB and TN of chum salmon in the central Bering Sea 2001-2003. The ROB, OB, COB and TN correspond to the brain loci shown in Fig. 1. Fish were divided into immature fish and maturing adult I and II, as shown in the inset. They are a portion of the fish used in Onuma et al. (2009a). The number of 
fish was 5-10 in each group. Each value represents mean \pm standard error. Significant differences among groups are identified with different letters $(\mathrm{p}<0.05$ one-way ANOVA and Tukey’s test).

Supplemental Figure 4 Amounts of sGnRH mRNA in the PM, NT and MT and amounts of cGnRH-II mRNA in the MT of chum salmon in the central Bering Sea 2001-2003. The PMp + PMm, PMg + NT and MT correspond to the brain loci shown in Fig. 1. Fish were divided into immature fish and maturing adult I and II, as shown in the inset. They are a portion of the fish used in Onuma et al. (2009a). The number of fish was 5-10 in each group. Each value represents mean \pm standard error. Significant differences among groups are identified with different letters ( $\mathrm{p}<0.05$ one-way ANOVA and Tukey’s test). 


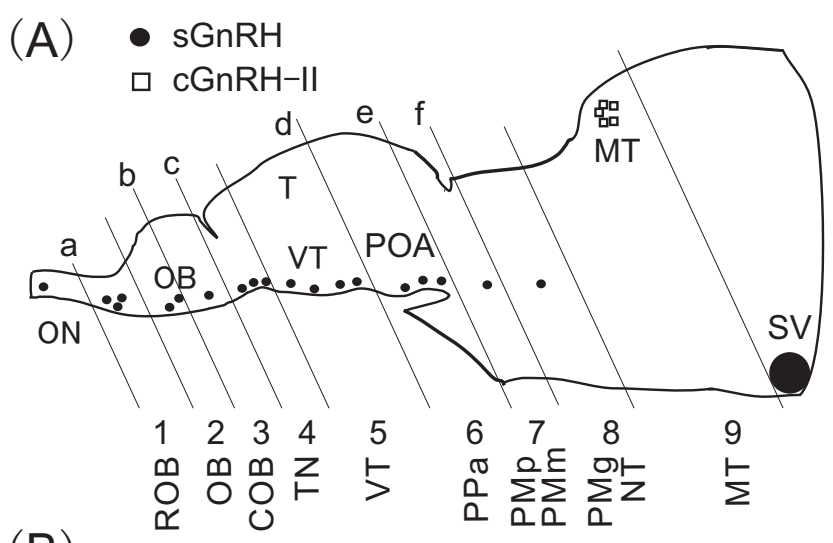

(B)

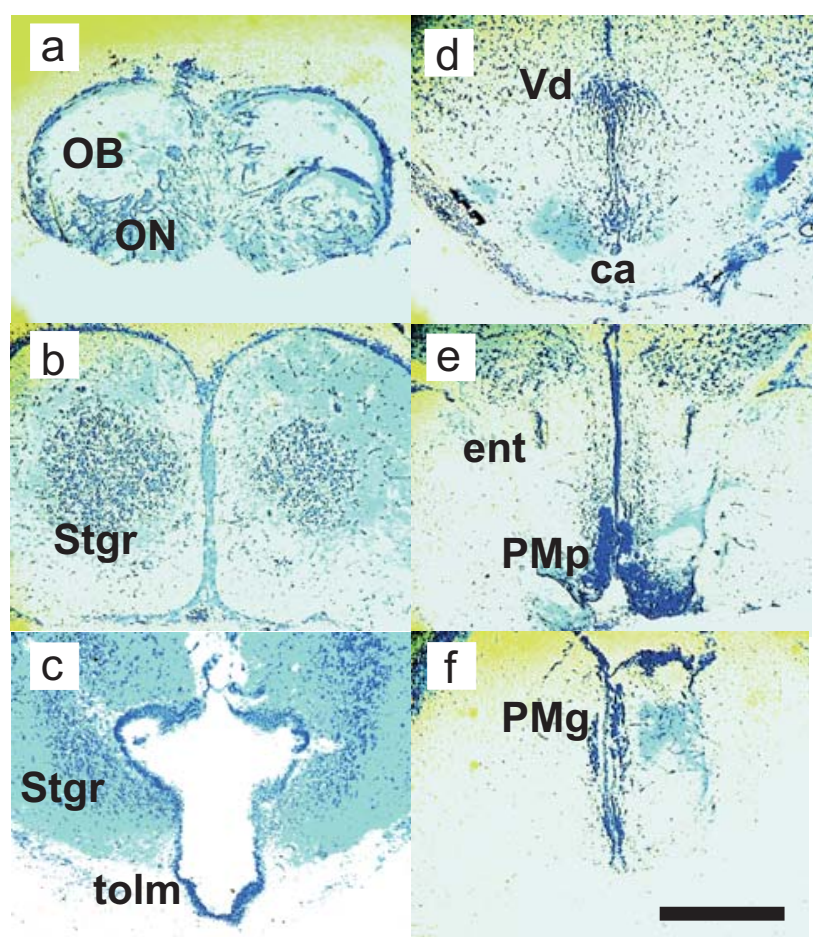

Figure 1 Onuma et al. 


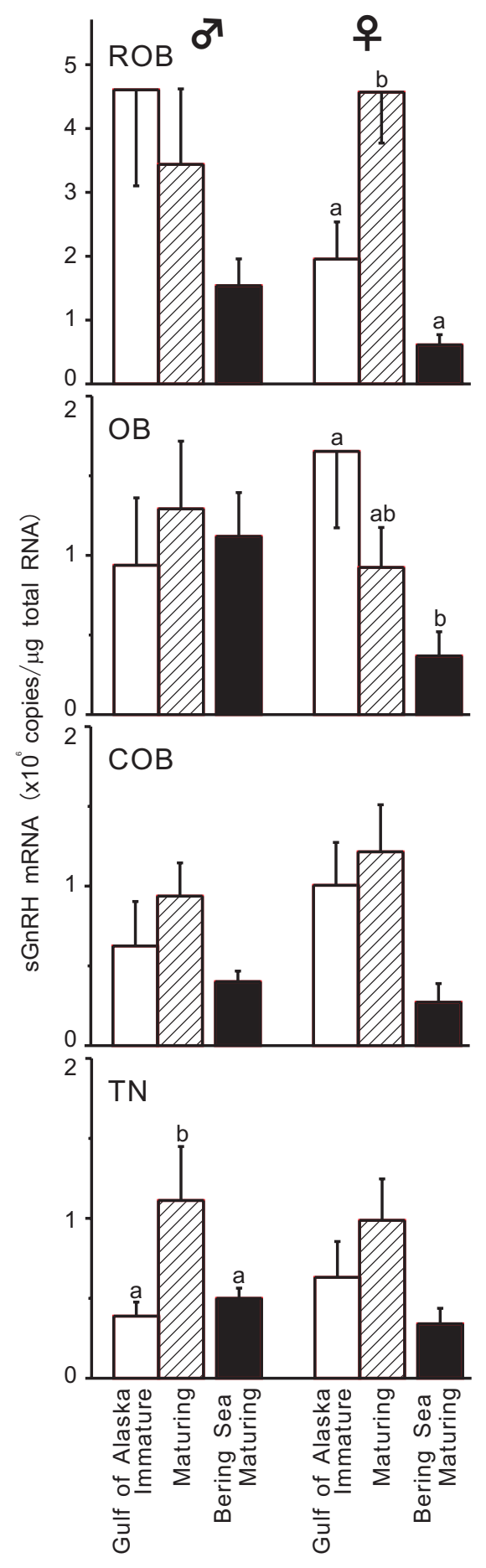

Figure 2

Onuma et al. 


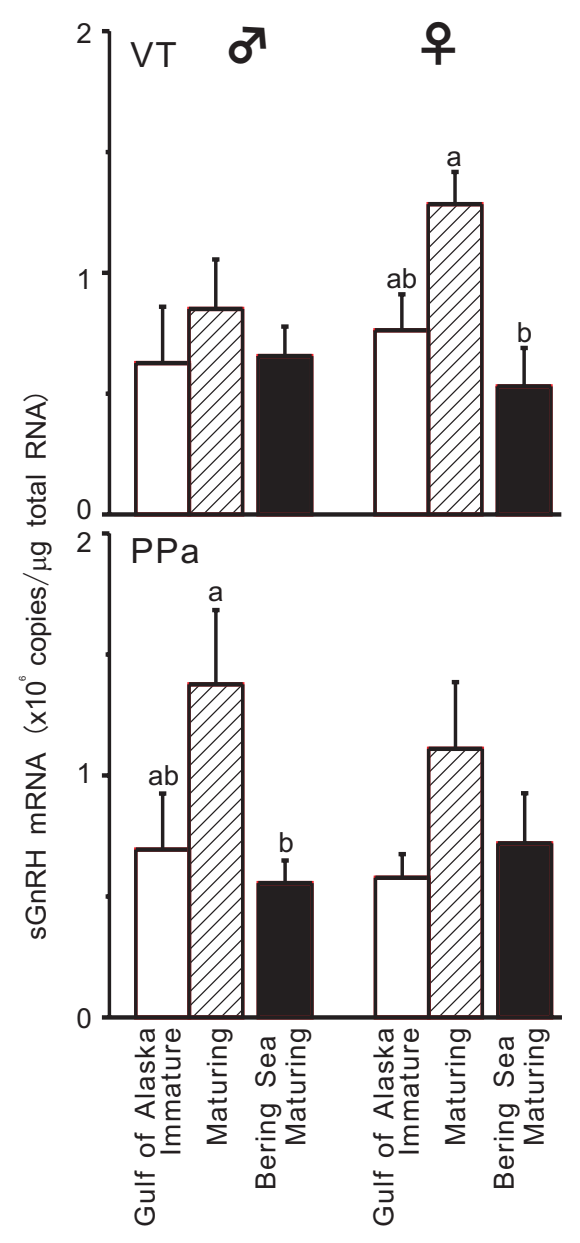

Figure 3 Onuma et al. 


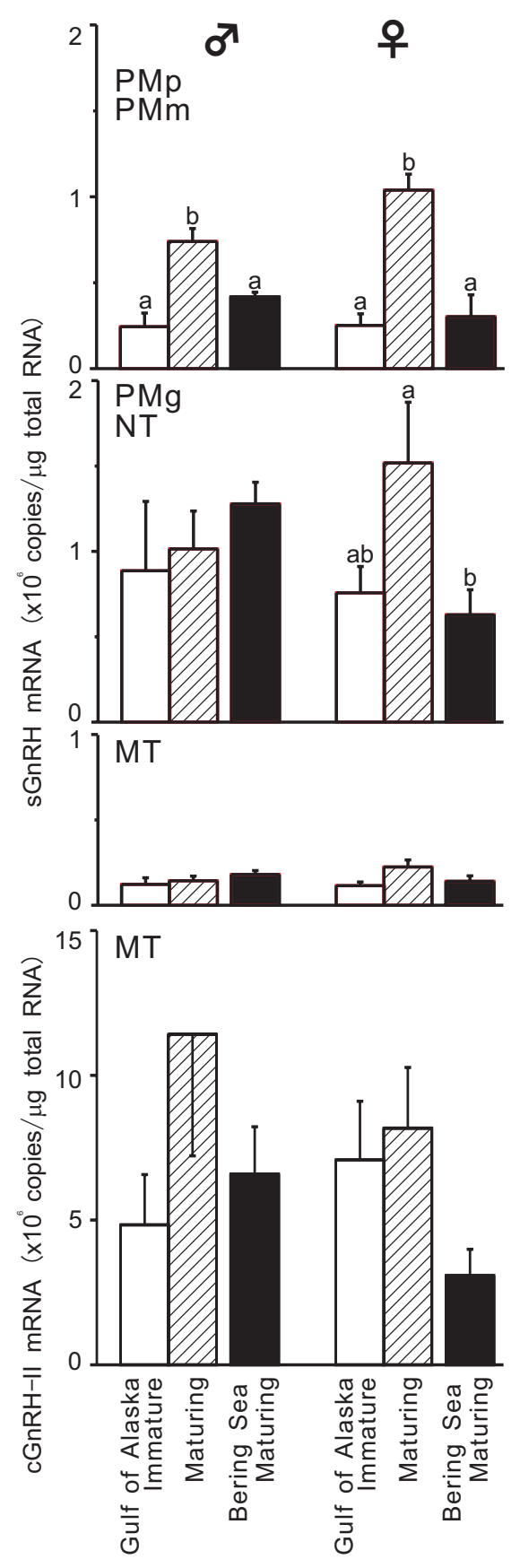

Figure 4

Onuma et al. 


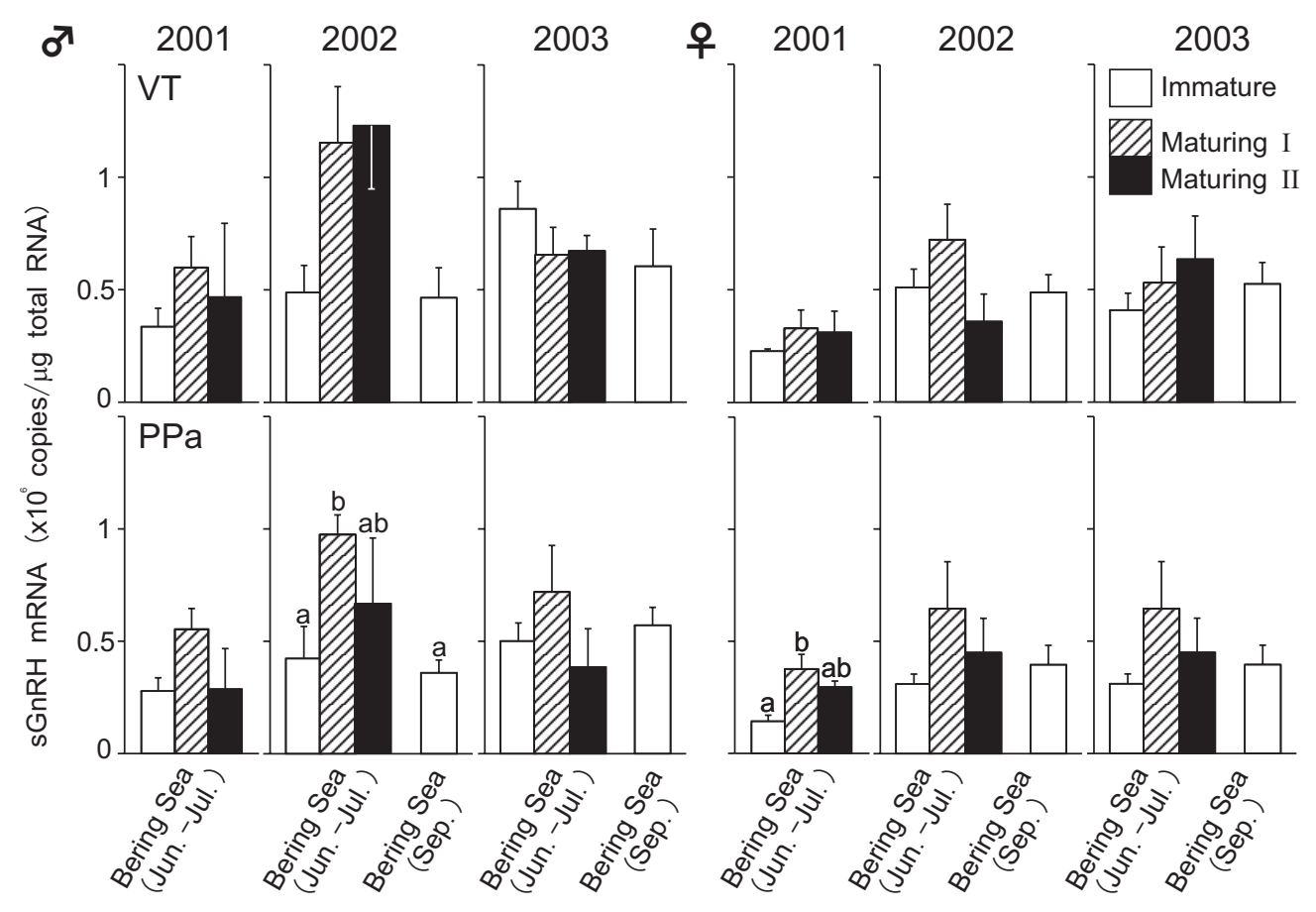

Figure 5

Onuma et al. 


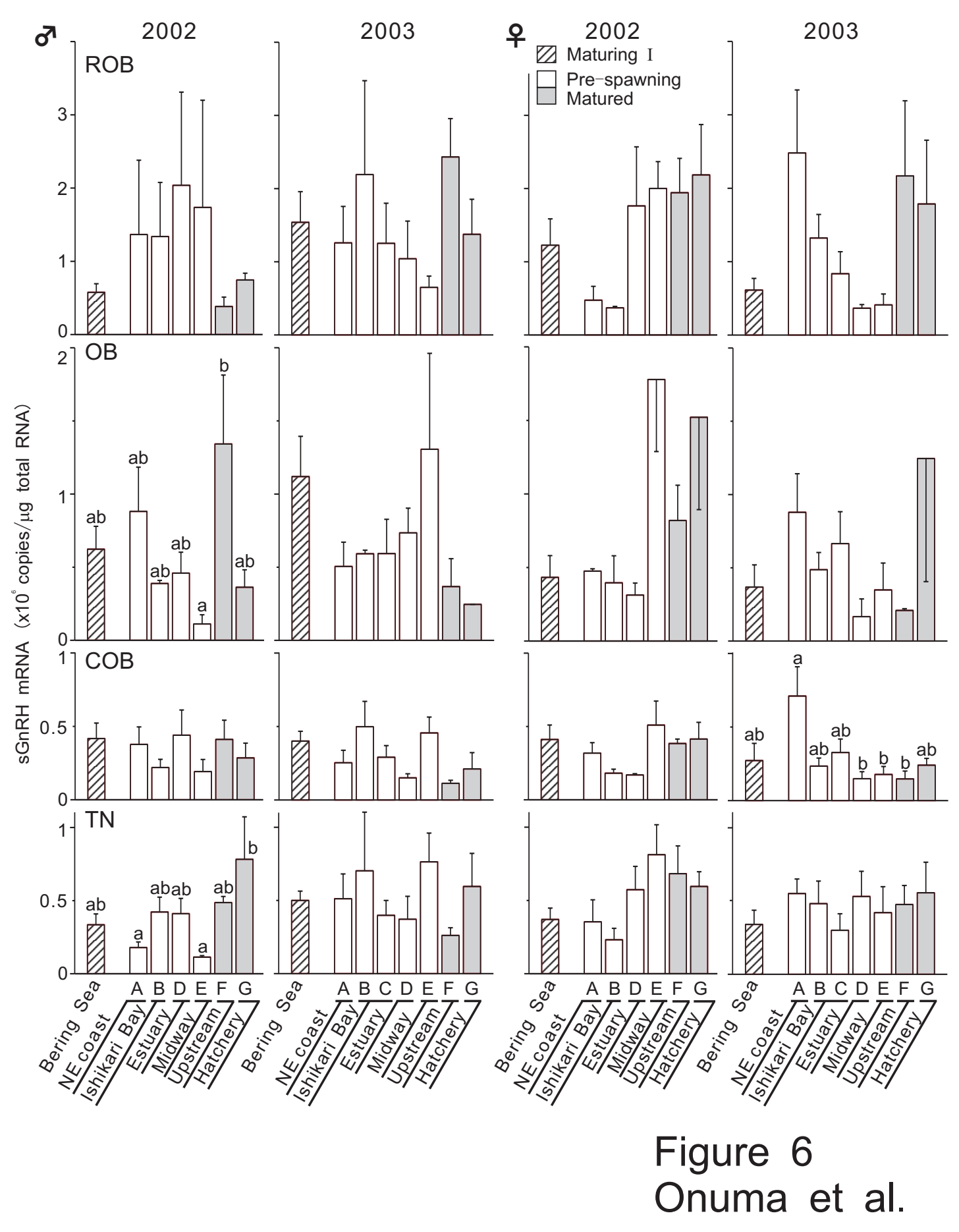




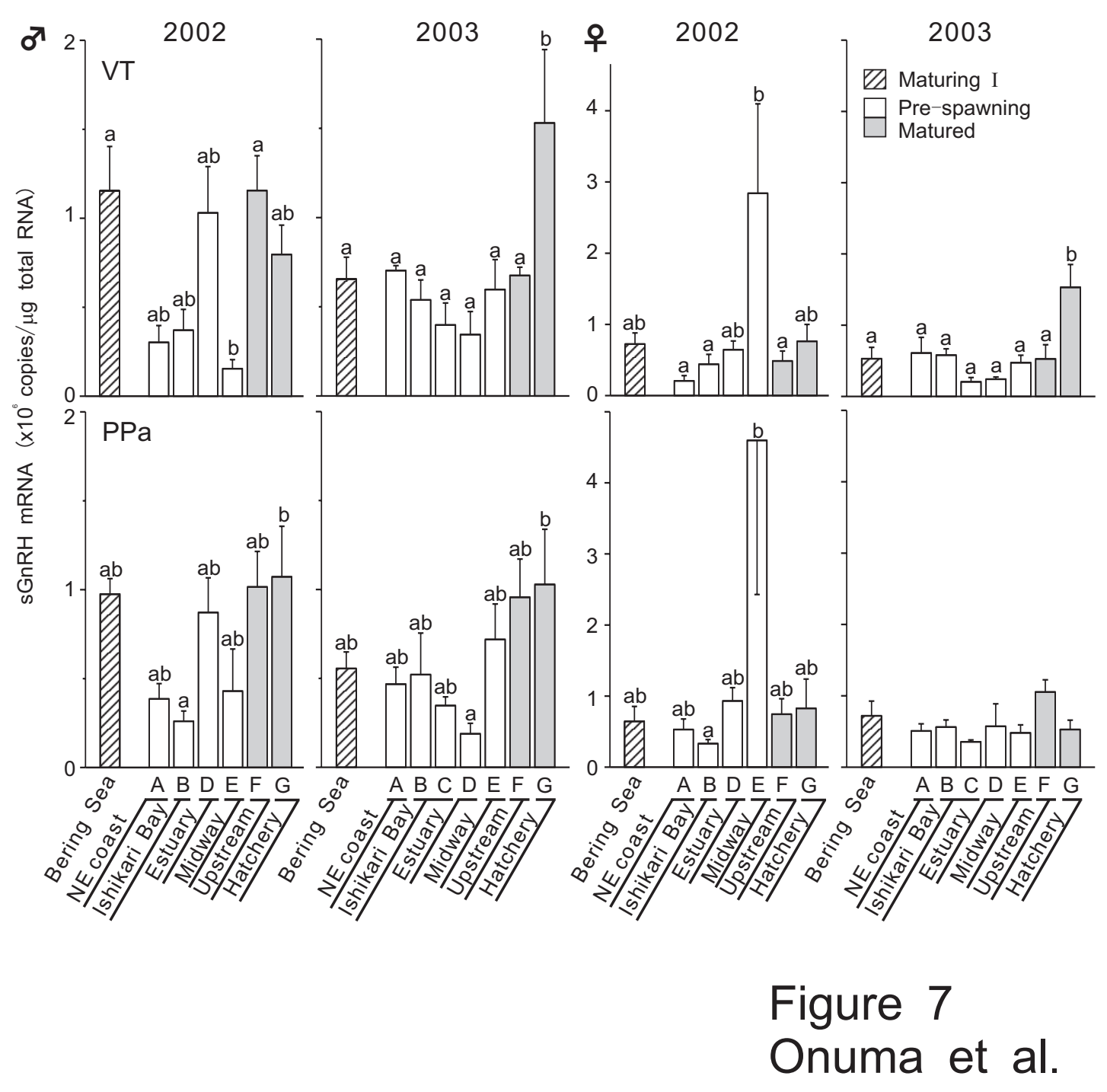




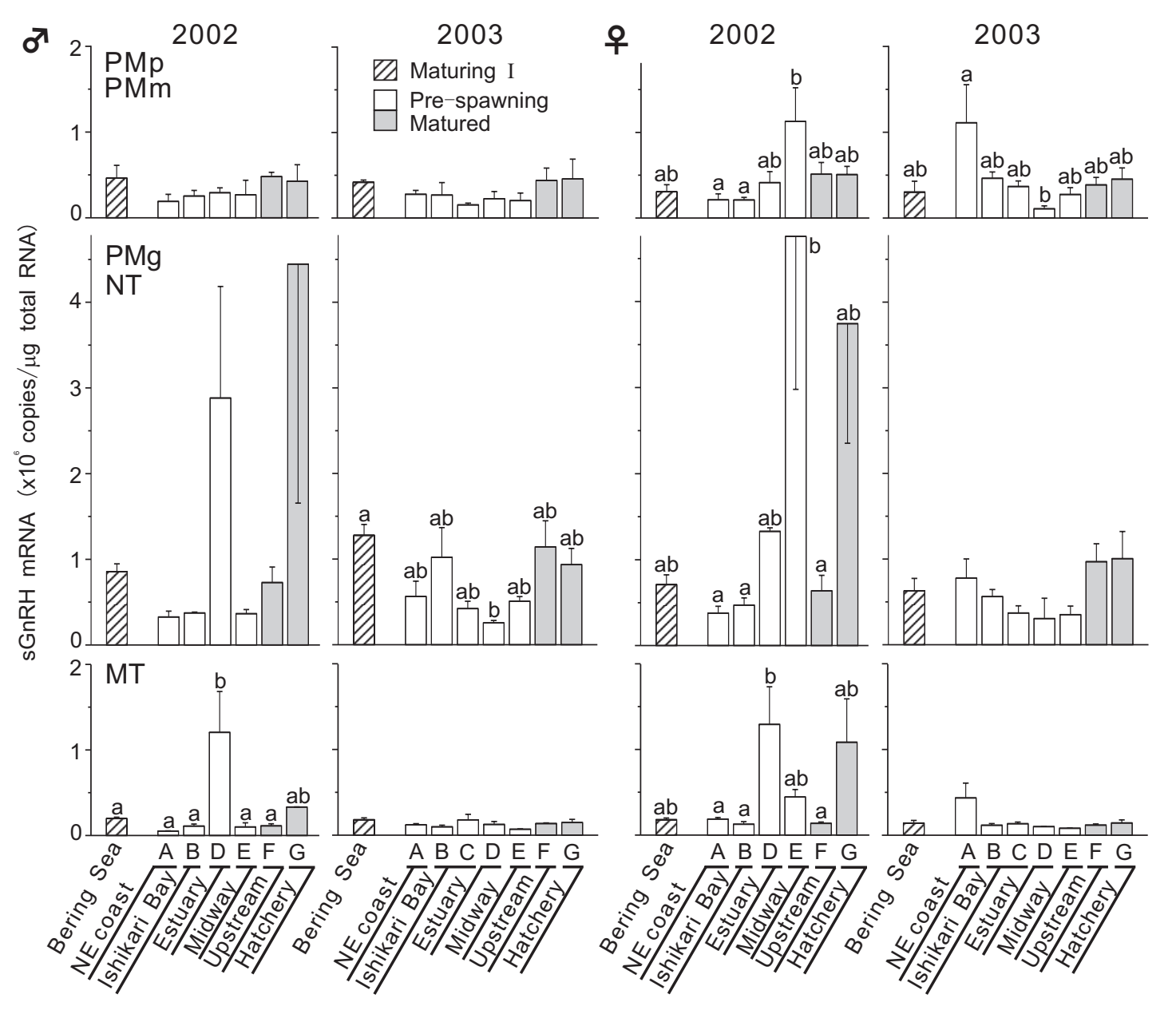

Figure 8

Onuma et al. 


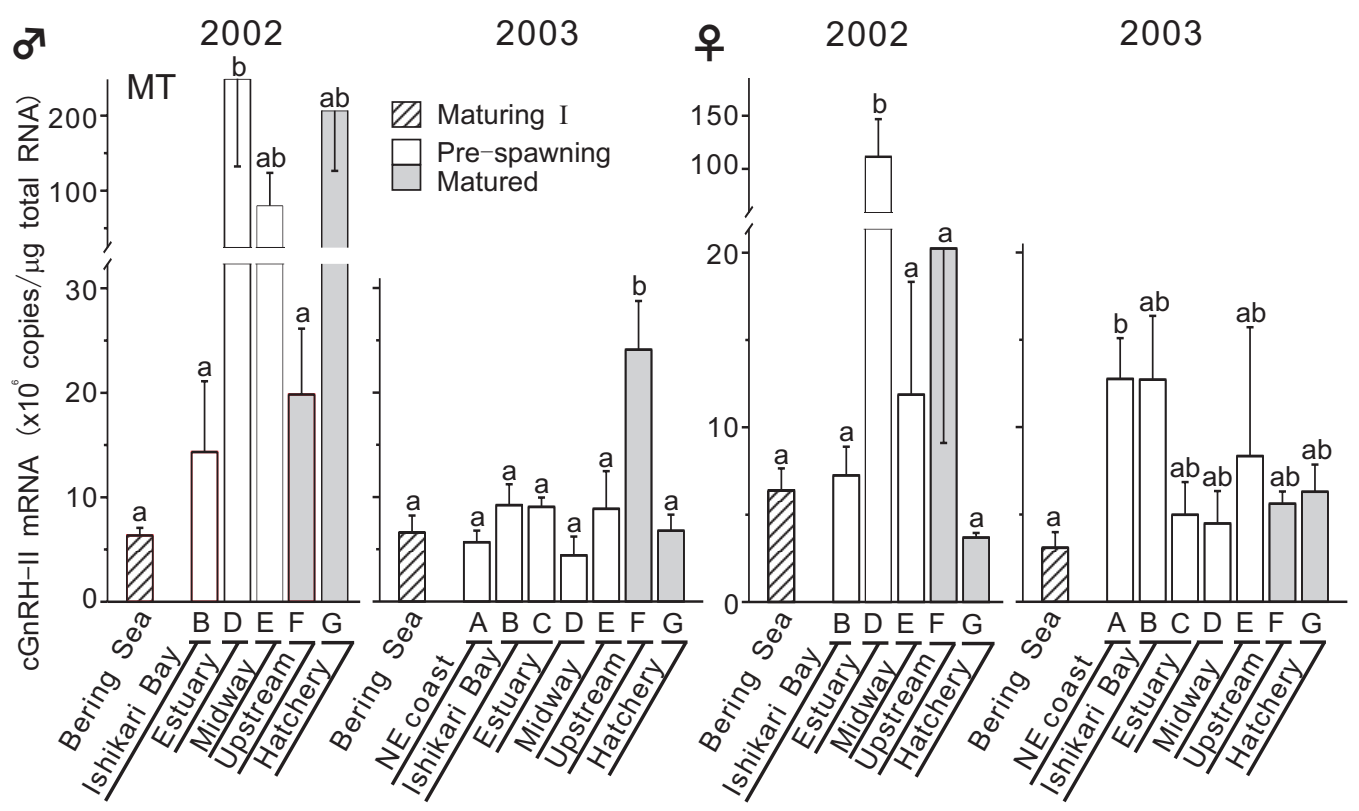

Figure 9

Onuma et al. 


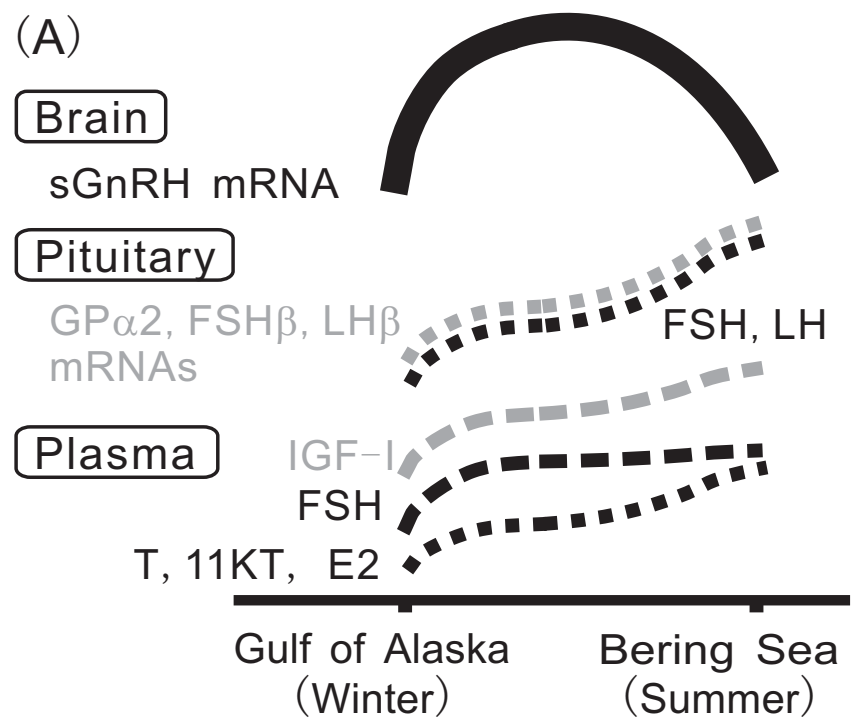

(B)

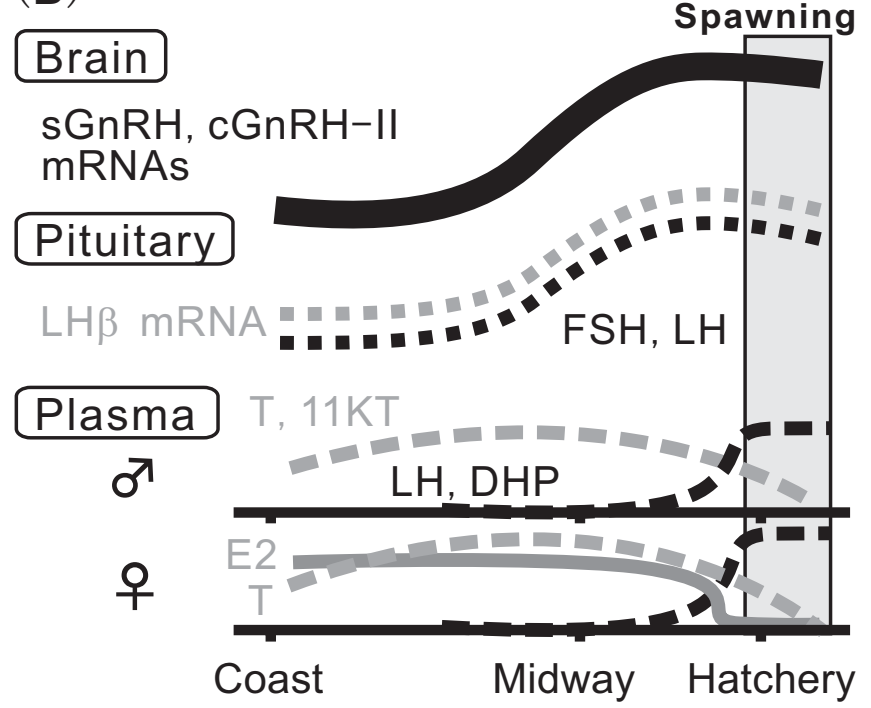

Figure 10

Onuma et al. 